- Доступность к транспорту сама помогает в развитии социальных сетей и связи между людьми - и, следовательно, социальная интеграция. Имея возможность доступа к общественному транспорту, хороший уровень взаимодействия между людьми способствует чувству принадлежности и укрепляет сообщества, что, в свою очередь, создает возможности и потенциал в сообществе [3, с.121].

В свою очередь, расширенные социальные сети, доступные такси могут помочь человеку добиться занятости и интеграции. Однако проблема наблюдается в отдельных регионах с более бедными системами общественного транспорта с ограниченной доступностью. Эта проблема также наблюдается в отношение к образованию, детиинвалиды не могут получить доступ к школьному автобусу в некоторые районы. Эта проблема препятствуют участию в школе, ухудшают поведение в школе (из-за усталости и раздражительности). Транспортные услуги являются частью системы - не только транспортных услуг, но и других процессов.

К сожалению, заставить эти элементы работать вместе непросто, так как каждая ссылка с участием различных участников, в том числе государственных и местных органов власти, правительственных инструментов, поставщиков услуг, управляющие инфраструктурой и сопутствующими услугами и другие лица, и организации, которые могут оказать помощь (формально или неформально) должны работать сообща.

На наш взгляд было бы целесообразнее совершить позитивный шаг вперед с точки зрения интеграции различных транспортных систем и обеспечения социальной интеграции инвалидов: создавать пункт бронирования и планирования для всех автобусов, реагирующих на спрос. Чтобы данная услуги, включая общественный транспорт и гибкие общественные автобусы. Пассажиры, которым требуется транспорт, будут отправлять запрос, указывая любые особые потребности, затем они бронируют услуги через одну центральную точку, либо через Интернет, введя коды в телефон на сенсорной панели или позвонив в центр бронирования.

Услуги могут включать в себя гибкие автобусные услуги или сообщества транспортного обслуживания. Подобная транспортная система работает в Австралии. Внедрения зарубежного опыта услуги по бронированию и планированию станет важным шагом вперед в вопросе интеграции инвалидов в общество.

$$
* * *
$$

1. Технология социальной работы: учебник / М.В. Фирсов, Е.Г. Студёнова. - М.: КНОРУС, 2016. $-344 \mathrm{c}$.

2. Тындик А.О., Васин С.А. Положение детей-инвалидов и их семей в зеркале переписей населения // Журнал исследований социальной политики. 2016. № 2. С. 167-180.

3. Холостова Е. И. Зарубежный опыт социальной работы: Учебное пособие / Е. И. Холостова, А. Н. Дашкина, И. В. Малофеев. - М.: Издательско-торговая корпорация «Дашков и К», 2013. — 368 с.

\title{
Хаджимурадова T.X. \\ Договор на оказание медицинской помощи по обязательному медицинскому страхованию
}

ФГБОУ ВО Чеченский государственный университет

(Россия, Грозный)

doi: 10.18411/lj-04-2021-315

\section{Аннотация}

Актуальность темы обусловлена необходимостью медицинского страхования, как неотъемлемой части поддержки населения.

Ключевые слова: страхование, медицина, договор. 
Abstract

The relevance of the topic is due to the need for health insurance, as an integral part of the support of the population.

Keywords: insurance, medicine, contract.

В Российской Федерации существует два вида медицинского страхования населения - обязательное и добровольное. Для получения медицинской помощи по системе обязательного страхования необходимо заключить три вида договоров договоры на организацию и финансирование медицинских услуг, договоры на медицинское страхование и договоры на оказание медицинской помощи.

Структура взаимоотношений и порядок выплат зависят от социального статуса, застрахованного (гражданин, работающий на предприятии, работник свободных профессий или лицо, занимающееся индивидуальной трудовой деятельностью, безработный, ребенок или пенсионер).

После заключения договора застрахованный получает справку на свое имя, по которой он может получать медицинские услуги в любой точке Российской Федерации в рамках предусмотренного обязательного медицинского страхования.

Добровольное медицинское страхование гарантирует гражданину дополнительные услуги сверх установленной программы обязательного медицинского страхования, оплачивая его за свой счет.

Добровольное медицинское страхование может быть предложено отдельным лицам или группам, или коллективам, например, персонал предприятия, и позволяет охваченному населению получать дополнительные услуги помимо тех, которые включены в базовый пакет. Он предлагается исключительно частными страховыми компаниями (обычно акционерными холдингами), которые работают с целью получения прибыли, хотя нет никаких препятствий для некоммерческих организаций, выходящих на поле.

Добровольное страхование играет лишь очень небольшую роль в предоставлении медицинской помощи в Российской Федерации, где полисы имеют менее $1 \%$ населения. Эта цифра возрастает до 24\% в Санкт-Петербурге и примерно 3$5 \%$ в Москве, но в других странах подписка остается низкой, а доля расходов, полученных в результате добровольного страхования, в целом составляет не более $2 \%$. Как правило, его покупают только богатые и небольшое количество работодателей для своих сотрудников (в дополнение к обязательным страховым взносам). Иностранные фирмы, в частности, стремятся обеспечить частную страховку для своих иностранных сотрудников [1, с.142].

Частные страховые компании, как правило, концентрируются на верхнем сегменте рынка и предлагают дополнительные услуги в дополнение к базовому пакету бесплатной медицинской помощи. Акцент был сделан на предоставлении лучших условий и гостиничных услуг, а также на обеспечении доступа к более престижным учреждениям. Компании, как правило, заключают контракты с клиниками и больницами, которые ранее входили в закрытую систему и которые были лучше обеспечены ресурсами даже в советское время.

Таким образом, они могут гарантировать своим клиентам доступ к лучшим средствам и высококвалифицированному персоналу, не неся при этом полной стоимости этого положения. Таким образом, выгоды от сделок со страховыми компаниями распространяются почти исключительно на те части системы, которые уже являются наиболее привилегированными.

Для заключения договора добровольного медицинского страхования застрахованная сторона направляет письменное уведомление страховой компании, которая должна принять решение в течение пяти дней с момента получения уведомления. 
Медицинские страховые компании не имеют законного права проводить производственные, коммерческие или банковские операции. Таким компаниям запрещено покупать или продавать недвижимость, хотя недвижимость можно приобрести как одну из форм инвестирования средств и страховых резервов. Органы управления здравоохранением и медицинские учреждения не имеют права быть учредителями медицинских страховых компаний, но могут владеть акциями, чья сумма не может превышать 10 процентов от страховой медицинской компании. Медицинская страховая компания должна иметь собственный капитал не менее 1200 раз минимальной годовой заработной платы, установленной правительством Российской Федерации. Резервные фонды по видам страхования формируются за счет вложений от 15 до 20 процентов средств, полученных по договорам страхования [2, с.119].

Медицинская страховая компания, осуществляющая обязательное медицинское страхование, не имеет права использовать средства, предназначенные для осуществления программ обязательного страхования, в коммерческих целях, за исключением временного приобретения очень ликвидных ценных бумаг и банковских вкладов с использованием свободных средств резервов. Средства обязательной страховой компании формируются за счет отчислений, сделанных из всех видов компаний, учреждений, всех видов имущественных организаций, а также из взносов, выплачиваемых лицами, осуществляющими свою собственную деятельность.

Окончательный финансовый итог (прибыль или убыток) по обязательному медицинскому страхованию состоит из финансового результата от операций медицинского страхования, размещения страховых резервов (оплата медицинских услуг, дополнительных финансовых профилактических мер) и дохода от операций, не связанных со страхованием и распределением резервов на обязательное медицинское страхование, за вычетом суммы расходов на эти операции. Финансовый результат операций по обязательному медицинскому страхованию определяется как разница между суммой страховых выплат, полученных вместе с доходами по страховым резервам за предыдущий год, и расходами на оплату медицинских услуг вместе с вычетами в страховых резервах. сумма затрат на ведение операций и сумма превышения прочих расходов над доходами.

В течение срока действия договора о добровольном медицинском страховании после признания судом невозможности застрахованного лица права и обязанности застрахованного лица передаются опекуну или попечителю, действующему в его интересах. В соответствии с законом о добровольном медицинском страховании застрахованным лицом не может быть гражданин, получающий лечение в диспансере от наркомании, психоневрологических проблем, туберкулеза, кожных и венерических заболеваний. Для людей, отбывающих тюремные сроки, Срок действия договора о добровольном медицинском страховании распространяется до окончания срока тюремного заключения или лишения свободы.

Правила договора. Застрахованная сторона имеет право досрочно расторгнуть договор добровольного медицинского страхования, если страховая компания не выполняет свои обязательства. В этом случае страховые взносы возвращаются застрахованному лицу, пропорционально рассчитанные на основе того, что страховая компания получила до момента расторжения договора за вычетом расходов. Для заключения договора застрахованная сторона должна пройти медицинское обследование на наличие определенных рисков. Если застрахованный умышленно скрыл факты о своем здоровье или предоставил ложную информацию, это является основанием для страховой компании отменить страховой полис или наложить санкции.

Добровольное медицинское страхование осуществляется за счет средств отдельного гражданина или берется из прибыли предприятия, действующего в его интересах. Отдельные категории клиентов (например, инвалиды) могут быть застрахованы на базовых условиях, соответствующих конкретным рискам категории, 
ограниченной сферой ответственности и расчетом повышенного уровня тарифа. Медицинская страховая компания (страховщик) обязана предоставить застрахованному гражданину (застрахованному лицу) медицинский полис и страховую карточку с его именем [3, с.14].

Роль медицинской страховой компании. Медицинская страховая компания не входит в систему здравоохранения Российской Федерации, и сама не оказывает медицинской помощи. В случае обязательного медицинского страхования страховщик обязан организовать и профинансировать оказание медицинских услуг в объеме и качестве, определенных программой обязательного медицинского страхования. В случае добровольного медицинского страхования страховщик обязан оплачивать и организовывать медицинские и социальные услуги, предусмотренные в программе добровольного медицинского страхования в дополнение к установленной программе обязательного медицинского страхования.

$$
* * *
$$

1. Куликов, Л.М. Основы экономических знаний: учеб.пособие. - М.: Финансы и статистика, 2009. $142 \mathrm{c}$.

2. Купрянова 3.М. Оценка трудящихся на рынке труда. (Российский центр изучения общественного мнения (ВЦИОМ)), 2012. -№ 6 - С. 119.

3. Кравченко, А. И. Социология управления: фундаментальный курс. учебное пособие для студентов вузов, обучающихся по специальности «Социология» / А. И. Кравченко, И. О. Тюрина. - М.: Академический проект. Екатеринбург: Деловая книга, 2008. 14 с.

\section{Хаджимурадова T.X. \\ Особенности правового регулирования мер социальной поддержки безработных}

ФГБОУ ВО Чеченский государственньй университет (Россия, Грозный)

doi: 10.18411/lj-04-2021-316

\section{Аннотация}

Актуальность темы исследования заключается в необходимости применения программ сохранения рабочих мест и создания частично финансируемого фонда занятости, исключительно для размещения целевых категорий безработных. В целях поддержки безработных.

Ключевые слова: безработица, социальная поддержка, занятость.

\section{Abstract}

The relevance of the research topic lies in the need to apply programs to preserve jobs and create a partially funded employment fund, exclusively for the placement of target categories of the unemployed. In order to support the unemployed.

Keywords: unemployment, social support, employment.

Служба занятости должна частично компенсировать только те расходы на создание рабочих мест, которые помогут обеспечить гарантированную занятость на определенный период времени для групп безработных, остро нуждающиеся в поддержке и трудоустройстве (инвалиды, одинокие родители, беженцы, вынужденные переселенцы, длительно безработные и т. д.). Приказ также предусматривал, что ресурсы из Фонда занятости должны выделяться на создание рабочих мест на конкурсной основе и что субсидии должны быть возмещаемыми или невозмещаемыми, в зависимости от категории лица, обеспеченного работой. Планируется разработать правовую базу для установления квот рабочих мест для социально уязвимых групп населения [1, с.78]. 